\title{
Evaluation of the effectiveness of the national vitamin A supplementation programme among school children in Sri Lanka
}

\author{
Thennakoon M. J. C. Madatuwa ${ }^{1}$, Sanath T. C. Mahawithanage ${ }^{2}$, Udumalagala G. Chandrika ${ }^{3}$, \\ Errol R. Jansz ${ }^{3}$ and Ananda R. Wickremasinghe ${ }^{4}$ \\ ${ }^{1}$ Medical Officer of Health/Divisional Director of Health Services Office, Yatiyantota, Kegalle, Sri Lanka \\ ${ }^{2}$ Department of Applied Nutrition, Faculty of Livestock, Fisheries and Nutrition, Wayamba University of Sri Lanka, Kuliyapitiya, \\ Sri Lanka \\ ${ }^{3}$ Department of Biochemistry, Faculty of Medical Sciences, University of Sri Jayewardenepura, Nugegoda, Sri Lanka \\ ${ }^{4}$ Department of Community and Family Medicine, Faculty of Medicine, University of Kelaniya, P.O. Box 06, Thalagolla Road, \\ Ragama, Sri Lanka
}

(Received 22 May 2005 - Revised 28 June 2006 - Accepted 28 June 2006)

\begin{abstract}
The Ministry of Health in Sri Lanka commenced a vitamin A supplementation programme of school children with a megadose of $105 \mu$ mol (100000 IU) vitamin A in school years 1, 4 and 7 (approximately 5-, 9- and 12-year-olds, respectively) in 2001. We evaluated the vitamin A supplementation programme of school children in a rural area of Sri Lanka. A cross-sectional study was conducted among children supplemented with an oral megadose of vitamin A $(105 \mu \mathrm{mol} ; n$ 452) and children not supplemented (controls; $n$ 294) in Grades $1-5$. Children were clinically examined and a sample of blood was taken for serum vitamin A concentration estimation by HPLC. Socio-demographic information was obtained from children or mothers. Supplemented children had a higher proportion of males and stunted children, were younger and lived under poorer conditions as compared to controls. There was no difference in the prevalences of eye signs and symptoms of vitamin A deficiency in the two groups. Supplemented children had higher serum vitamin A concentrations than controls (1.4 (SD 0.49) $\mu \mathrm{mol} / 1$ v. 1.2 (SD 0.52) $\mu \mathrm{mol} / 1)$. The serum vitamin A concentrations were 1.6 (SD 0.45), 1.4 (SD 0.50), 1.3 (SD 0.44) and 1.1 (SD 0.43) $\mu \mathrm{mol} / 1$ in children supplemented within 1, 1-6, 7-12 and 13-18 months of supplementation, respectively. Vitamin A concentrations were significantly greater than controls if supplementation was carried out within 6 months after adjustment. The oral megadose of $105 \mu \mathrm{mol}$ vitamin A maintained serum vitamin A concentrations for 6 months in school children.
\end{abstract}

Vitamin A supplementation: School children: Oral megadose: Vitamin A concentrations: Sri Lanka

Vitamin A deficiency is a significant public health problem throughout the world, affecting millions of school children. Among the proposed strategies to correct the deficiency, the distribution of capsules containing a high dose of preformed vitamin A to at-risk populations is practised and supported widely by international organizations due to its immediate impact and the possibility of it being implemented via the existing health care infrastructure (Sommer, 1989).

Vitamin A deficiency is a public health problem in Sri Lanka (Medical Research Institute, 1998). The Government of Sri Lanka in its national plan of action aimed to achieve virtual elimination of vitamin A deficiency and its consequences (Nutrition Division, 1999). The current national programme of vitamin A supplementation, commenced in 2001, includes using an oral megadose of $210 \mu \mathrm{mol}$ (200000 IU) for postpartum mothers within 4 weeks of delivery, and $105 \mu \mathrm{mol}$ (100000 IU) for infants at 9 months with measles immunization, preschool children at 18 months with oral polio vaccine and diphtheria, pertussis and tetanus immunization, and school children in Grades 1, 4 and 7 (approximately 5-, 9- and 12-year-olds, respectively). Although the programme was initiated in 2001, not all schools were included initially due to logistic reasons and the supplementation programme was phased over a period of time. The interval between megadose supplementation in children ranges from 9 months (between first and second dose) to 3 years (between fourth and final dose) (Family Health Bureau, 2000).

Vitamin A intervention programmes require rigorous and repeated evaluation to ensure they are achieving their goal (Wasantwisut, 2002). The national vitamin A supplementation programme in Sri Lanka has not been evaluated for its efficacy at any level since its inception. We report here an evaluation of the programme in school children in a selected area of Sri Lanka.

\footnotetext{
Abbreviations: DDHS, Divisional Director of Health Services; MOH, Medical Officer of Health.

* Corresponding author: Prof. A. R. Wickremasinghe, fax +94 11295 8337, email arwicks@sltnet.lk
} 


\section{Materials and methods}

\section{Study site and subjects}

A cross-sectional study was carried out in the Yatiyantota Medical Officer of Health (MOH)/Divisional Director of Health Services (DDHS) area in the Kegalle District of the Sabaragamuwa Province from May to August 2002. Sri Lanka has nine provinces and each province is divided into districts and each district is divided into a number of $\mathrm{MOH} /$ DDHS areas administered by a MOH/DDHS. Each MOH/ DDHS area has a population ranging from 70000 to 100000 . The country is thus divided into $270 \mathrm{MOH} / \mathrm{DDHS}$ areas. In a survey carried out in 1995-6, the Sabaragamuwa province had the highest percentage of children with low serum retinol concentrations (less than $0.7 \mu \mathrm{mol} / \mathrm{l}$ ) (Medical Research Institute, 1998). Approximately half of the school children in the area were supplemented with the vitamin A oral megadose $(105 \mu \mathrm{mol})$ at the time of the survey. Each dose contained $105 \mu \mathrm{mol}$ vitamin A and $9 \cdot 1 \mathrm{mg}$ vitamin E. Capsules were manufactured by Accucaps Industries Ltd (Windsor, Canada). As supplementation was carried out in Grades 1 and 4, the survey was carried out among children in Grades 1, 2, 4 and 5. A sample of ninety-five children was required from each category to estimate a prevalence of night blindness of $1 \%$ with a $95 \%$ CI ranging from 0 to $3 \%$.

There were seventy-six schools in the area. The list of schools of the Yatiyantota DDHS area and their supplementation status were obtained from the DDHS. Supplemented children were recruited from seven randomly selected schools in which the supplementation programme was carried out. Non-supplemented children were recruited from two randomly selected schools in which the supplementation was not carried out.

\section{Evaluation of ocular manifestations of vitamin A deficiency}

Night blindness was assessed by history and by examining children in a dimly lit room at least 12 feet in length with several items of furniture (World Health Organization, 1996). Mothers and children were questioned about night blindness with appropriate terms in the local language to obtain a history of night blindness. All children were subject to a clinical examination to detect ocular manifestations of vitamin A deficiency by trained medical officers according to the guidelines specified by the World Health Organization (1995a).

\section{Socio-demographic and anthropometric data}

An interviewer-administered questionnaire was used to collect information on socio-demographic and health-related data. Anthropometric measurements were obtained according to WHO guidelines (World Health Organization, 1995b). The height of each child was measured to a precision of $0.1 \mathrm{~cm}$ using a measuring scale. Weights were measured to a precision of $0.1 \mathrm{~kg}$ using a digital electronic scale (Seca, Les Mureaux, France). The scale was standardised every twentyfifth to thirtieth measurement with standard weights of $500 \mathrm{~g}$ and 5 and $10 \mathrm{~kg}$. Previous heights and weights of the children were obtained from past school medical inspection records. Anthropometric indices were calculated using EPIINFO (Centers for Disease Control and Prevention, Atlanta, GA, USA) and children were classified as stunted, underweight or wasted if their $z$-score of height-for-age, weight-for-age or weight-for-height was less than two standard deviations below the National Center for Health Statistics median. zscores for weight-for-height were calculated for males up to 138 months (11.5 years) of age and less than $145 \mathrm{~cm}$ and for females up to 120 months (10 years) of age and less than $137 \mathrm{~cm}$.

\section{Collection of morbidity data}

Morbidity data were collected by questioning the mothers on the past history of diarrhoea and respiratory infections in children during the 4 weeks prior to the interview. Diarrhoea was defined as the passage of three or more loose motions a day and a respiratory infection was defined as the presence of cough with or without expectoration for at least $24 \mathrm{~h}$.

\section{Determination of serum vitamin A concentrations}

A $2 \mathrm{ml}$ sample of venous blood was drawn from each child and transferred at $4^{\circ} \mathrm{C}$ to a laboratory in Colombo within $4-5 \mathrm{~h}$ where serum was separated and stored at $-80^{\circ} \mathrm{C}$ until biochemical analysis. Serum vitamin A concentrations were assayed by reversed-phase HPLC according to the method of Bieri et al. (1979). A total of $200 \mu \mathrm{l}$ serum was added to $100 \mu \mathrm{l}$ standard solution of retinyl acetate and $100 \mu \mathrm{l}$ ethanol and serum vitamin A was extracted with $600 \mu l$ hexane. A $400 \mu l$ portion of the hexane extract was evaporated to dryness under a stream of nitrogen gas, re-dissolved in $100 \mu l$ mobile phase, and injected on to a $\mathrm{C}_{18}$, reversed phase $150 \mathrm{~mm} \times 4.6 \mathrm{~mm}$ HPLC column ( $5 \mu \mathrm{m}$ particle size; Waters, MA, USA). The mobile phase (methanol-water, 95:5 v/v) was delivered at a flow rate of $1 \mathrm{ml} / \mathrm{min}$. Vitamin A (eluting time $4 \mathrm{~min}$ ) was detected at $325 \mathrm{~nm}$ in a Beakman ultraviolet detector. The vitamin A concentration was quantified to the peak area of the internal retinyl acetate standard. The CV was $7.2 \%$ and inter-batch $\mathrm{CV}$ was $5.8 \%$. Serum vitamin A values are reported in $\mu \mathrm{mol} / \mathrm{l}$.

\section{Statistical analyses}

Data analyses were carried out using SPSS (SPSS Inc., Chicago, IL, USA). $t$ Tests, $\chi^{2}$ tests and regression analysis were used to detect associations.

\section{Ethical aspects}

Ethical clearance to conduct the study was obtained from the Ethical Review Committee of the Faculty of Medical Sciences, University of Sri Jayewardenepura. Permission to conduct the study was obtained from the Deputy Provincial Director of Health Services, Kegalle District, the Zonal Director of Education, Dehiowita, and all principals of schools selected for the study. Children were recruited into the study after obtaining written informed consent from their parents or guardians. Children detected with signs of vitamin A deficiency were given an oral megadose of vitamin A. Children with other medical conditions were referred appropriately. 


\section{Results}

A total of 746 students from nine schools in the Yatiyantota $\mathrm{MOH} / \mathrm{DDHS}$ area were recruited into the study. A total of 452 children from seven schools were supplemented with vitamin A. The rest ( $n$ 294) were not supplemented. The sociodemographic profile of the children is given in Table 1 .

The majority of the non-supplemented children were female, older than 9 years and lived in permanent houses. Mothers of supplemented children were more educated than mothers of non-supplemented children.

The prevalence of eye signs and symptoms among school children was extremely low and there was no difference between supplemented and non-supplemented children (Table 2). When the analyses were performed considering the sexes separately, there was no significant difference in nutritional status between supplemented and non-supplemented boys. Girls supplemented with vitamin A tended to be more malnourished than their nonsupplemented counterparts (data not shown). Among non-supplemented children, only one case of night blindness was detected by history. Among supplemented children, five children had night blindness by dark adaptometry.

Although the nutritional status of supplemented children was poorer than that of the non-supplemented children, only the difference for height-for-age was statistically significant
(Table 2). There was no significant difference in the reported incidence of infections between the two groups of children.

Of the supplemented children who were stunted at the last school medical examination $53 \%$ were normal in the current survey (Table 3). Among the non-supplemented children classified as stunted in the last school medical examination, $23 \%$ were classified as normal in the current survey.

Serum vitamin A concentrations of supplemented children (1.4 (SD 0.49) $\mu \mathrm{mol} / \mathrm{l})$ were significantly higher than those of controls $(1.2(\mathrm{SD} 0.52) \mu \mathrm{mol} / \mathrm{l})(P=0.003)$. Serum vitamin A concentrations declined gradually from the time of supplementation (Table 4; Fig. 1). Serum vitamin A concentrations of the children who were supplemented more than 6 months prior to the survey (1.3 (SD 0.44) $\mu \mathrm{mol} / 1$ in those supplemented 7-12 months back and 1.1 (SD 0.44) $\mu \mathrm{mol} / 1$ in those supplemented 13-18 months back) were similar to those of control children (1.2 (SD 0.52) $\mu \mathrm{mol} / 1)$. Children who were supplemented within 1 month had the highest serum vitamin A concentrations (1.6 (SD 0.45) $\mu \mathrm{mol} / \mathrm{l})$ followed by children supplemented $1-6$ months (1.4 (SD 0.50) $\mu \mathrm{mol} / \mathrm{l})$ previously.

In a multiple regression analysis, taking serum vitamin $\mathrm{A}$ concentrations as the dependent variable, time since supplementation ( $<1$ month, 1-6 months, 7-12 months and $>12$ months) was the only significant predictor of serum vitamin A concentrations after controlling for other variables

Table 1. Socio-demographic profile of children

\begin{tabular}{|c|c|c|c|c|c|c|}
\hline \multirow[b]{2}{*}{ Variable } & \multicolumn{2}{|c|}{ Supplemented } & \multicolumn{2}{|c|}{ Non-supplemented } & \multirow[b]{2}{*}{$x^{2}$} & \multirow[b]{2}{*}{$P$ value } \\
\hline & $n$ & $\%$ & $n$ & $\%$ & & \\
\hline \multicolumn{7}{|l|}{ Sex } \\
\hline Male & 237 & $52 \cdot 4$ & 110 & 37.4 & \multirow{3}{*}{$16 \cdot 15$} & \multirow[t]{3}{*}{$<0.001$} \\
\hline Female & 215 & 47.6 & 184 & $62 \cdot 6$ & & \\
\hline Total & 452 & $100 \cdot 0$ & 294 & $100 \cdot 0$ & & \\
\hline \multicolumn{7}{|l|}{ Age (years) } \\
\hline$<7$ & 177 & $39 \cdot 3$ & 54 & 21.5 & \multirow[t]{4}{*}{$42 \cdot 40$} & \multirow[t]{4}{*}{$<0.001$} \\
\hline $7-9$ & 109 & $24 \cdot 2$ & 42 & $16 \cdot 7$ & & \\
\hline$>9$ & 164 & 36.4 & 155 & $61 \cdot 8$ & & \\
\hline Total & 450 & $100 \cdot 0$ & 294 & $100 \cdot 0$ & & \\
\hline \multicolumn{7}{|l|}{ Mother's education } \\
\hline Up to primary & 82 & $19 \cdot 2$ & 46 & $18 \cdot 0$ & \multirow[t]{4}{*}{$6 \cdot 76$} & \multirow[t]{4}{*}{0.034} \\
\hline Secondary & 147 & 34.4 & 113 & $44 \cdot 1$ & & \\
\hline$\geq$ GCE OL/AL & 198 & 46.4 & 97 & 37.9 & & \\
\hline Total & 427 & $100 \cdot 0$ & 256 & $100 \cdot 0$ & & \\
\hline \multicolumn{7}{|l|}{ Father's education } \\
\hline Up to primary & 89 & $21 \cdot 2$ & 41 & $16 \cdot 8$ & \multirow[t]{4}{*}{$3 \cdot 89$} & \multirow[t]{4}{*}{0.143} \\
\hline Secondary & 157 & 37.4 & 109 & $44 \cdot 7$ & & \\
\hline$\geq$ GCE OL/AL & 174 & 41.4 & 94 & 38.5 & & \\
\hline Total & 420 & $100 \cdot 0$ & 244 & $100 \cdot 0$ & & \\
\hline \multicolumn{7}{|l|}{ Father's occupation } \\
\hline Unskilled worker/labourers & 198 & $46 \cdot 2$ & 106 & $39 \cdot 6$ & \multirow[t]{6}{*}{$3 \cdot 82$} & \multirow[t]{6}{*}{0.431} \\
\hline Skilled workers & 130 & $30 \cdot 3$ & 84 & 31.3 & & \\
\hline Professional & 29 & $6 \cdot 8$ & 24 & $9 \cdot 0$ & & \\
\hline Business & 57 & 13.3 & 42 & $15 \cdot 7$ & & \\
\hline Not with the family/died & 15 & 3.5 & 12 & 4.5 & & \\
\hline Total & 429 & $100 \cdot 0$ & 268 & $100 \cdot 0$ & & \\
\hline \multicolumn{7}{|l|}{ Number of family members } \\
\hline$<5$ & 224 & $49 \cdot 8$ & 132 & $46 \cdot 1$ & \multirow[t]{3}{*}{0.92} & \multirow[t]{3}{*}{0.337} \\
\hline$\geq 5$ & 226 & $50 \cdot 2$ & 154 & 63.9 & & \\
\hline Total & 450 & $100 \cdot 0$ & 286 & $100 \cdot 0$ & & \\
\hline \multicolumn{7}{|l|}{ Type of house } \\
\hline Temporary/semi-permanent & 121 & $27 \cdot 0$ & 45 & $15 \cdot 6$ & \multirow[t]{3}{*}{$12 \cdot 43$} & \multirow[t]{3}{*}{$<0.001$} \\
\hline Permanent & 328 & 73.0 & 242 & 84.4 & & \\
\hline Total & 449 & $100 \cdot 0$ & 287 & $100 \cdot 0$ & & \\
\hline
\end{tabular}

GCE OL/AL, GCE 'O' level/'A' level. 
Table 2. Health profile of children

\begin{tabular}{|c|c|c|c|c|c|c|}
\hline \multirow[b]{2}{*}{ Variable } & \multicolumn{2}{|c|}{ Supplemented } & \multicolumn{2}{|c|}{ Non-supplemented } & \multirow[b]{2}{*}{$x^{2}$} & \multirow[b]{2}{*}{$P$ value } \\
\hline & $n$ & $\%$ & $n$ & $\%$ & & \\
\hline \multicolumn{7}{|l|}{ Ocular manifestations } \\
\hline \multicolumn{7}{|l|}{ Bitot's spots } \\
\hline Present & 6 & 1.3 & 1 & 0.3 & & \multirow[t]{2}{*}{$0.257^{*}$} \\
\hline Absent & 445 & 98.7 & 283 & 99.7 & & \\
\hline \multicolumn{7}{|l|}{ Conjunctival xerosis } \\
\hline Present & 9 & $2 \cdot 0$ & 6 & $2 \cdot 1$ & & \multirow[t]{2}{*}{$1.000^{*}$} \\
\hline Absent & 442 & 98.0 & 278 & 97.9 & & \\
\hline \multicolumn{7}{|c|}{ Night blindness by evaluation of dark adaptation } \\
\hline Present & 5 & 1.1 & 0 & 0.0 & & \multirow[t]{2}{*}{$0.163^{*}$} \\
\hline Absent & 446 & 98.9 & 284 & $100 \cdot 0$ & & \\
\hline \multicolumn{7}{|c|}{ Night blindness by history } \\
\hline Present & 5 & 1.1 & 1 & 0.3 & & \multirow[t]{2}{*}{$0.414^{*}$} \\
\hline Absent & 446 & 98.9 & 283 & 99.7 & & \\
\hline \multicolumn{7}{|l|}{ Anthropometric status $\dagger$} \\
\hline \multicolumn{7}{|l|}{ Weight-for-age } \\
\hline Underweight & 144 & $32 \cdot 1$ & 65 & $26 \cdot 3$ & \multirow[t]{3}{*}{2.571} & \multirow[t]{3}{*}{0.109} \\
\hline Normal & 304 & 67.9 & 182 & $73 \cdot 7$ & & \\
\hline Total & 448 & $100 \cdot 0$ & 247 & $100 \cdot 0$ & & \\
\hline \multicolumn{7}{|l|}{ Weight-for-height } \\
\hline Wasting & 80 & $19 \cdot 5$ & 34 & $16 \cdot 7$ & \multirow[t]{3}{*}{0.663} & \multirow[t]{3}{*}{0.416} \\
\hline Normal & 331 & 80.5 & 169 & 83.3 & & \\
\hline Total & 411 & $100 \cdot 0$ & 203 & $100 \cdot 0$ & & \\
\hline \multicolumn{7}{|l|}{ Height-for-age } \\
\hline Stunting & 81 & $18 \cdot 8$ & 28 & 11.3 & \multirow[t]{3}{*}{$6 \cdot 514$} & \multirow[t]{3}{*}{0.011} \\
\hline Normal & 351 & $81 \cdot 3$ & 220 & 88.7 & & \\
\hline Total & 432 & $100 \cdot 0$ & 248 & $100 \cdot 0$ & & \\
\hline \multicolumn{7}{|c|}{ Reported diseases 4 weeks prior to the survey } \\
\hline \multicolumn{7}{|c|}{ Diarrhoea } \\
\hline Experienced & 43 & 9.5 & 23 & 7.8 & \multirow[t]{2}{*}{3.07} & \multirow[t]{2}{*}{0.381} \\
\hline Not experienced & 409 & 90.5 & 271 & $92 \cdot 2$ & & \\
\hline Cough and cold & & & & & & \\
\hline Experienced & 302 & $66 \cdot 8$ & 181 & 61.6 & $2 \cdot 15$ & 0.142 \\
\hline Not experienced & 150 & 33.2 & 113 & 38.4 & & \\
\hline
\end{tabular}

*Fisher's Exact Test.

$\dagger$ Children were classified as stunted, underweight or wasted if their z-score of height-for-age, weight-for-age or weight-for-height was less than two standard deviations below the National Center for Health Statistics median.

(Table 5). Children who were supplemented within 6 months of the survey had a higher serum vitamin A concentration than controls. The difference was as much as $0.4 \mu \mathrm{mol} / 1$ within 1 month of the survey and $0.2 \mu \mathrm{mol} / 1$ between 1 and 6 months.

\section{Discussion}

The present study clearly shows that children supplemented with vitamin A within 1 month had a significantly higher concentration of vitamin A than those supplemented earlier. The ability

Table 3. Prevalence of stunting* in the last school medical examination and current survey in relation to vitamin A supplementation status

\begin{tabular}{|c|c|c|c|c|c|c|}
\hline \multirow[b]{3}{*}{ Vitamin A supplementation status } & \multicolumn{4}{|c|}{ Current survey } & & \\
\hline & \multicolumn{2}{|c|}{ Stunted } & \multicolumn{2}{|c|}{ Normal } & \multicolumn{2}{|c|}{ Total } \\
\hline & $n$ & $\%$ & $n$ & $\%$ & $n$ & $\%$ \\
\hline \multicolumn{7}{|l|}{ Supplemented } \\
\hline \multicolumn{7}{|l|}{ Last school medical examination } \\
\hline Stunted & 55 & $46 \cdot 6$ & 63 & $53 \cdot 4$ & 118 & $100 \cdot 0$ \\
\hline Normal & 15 & $06 \cdot 0$ & 235 & $94 \cdot 0$ & 250 & $100 \cdot 0$ \\
\hline \multicolumn{7}{|c|}{ McNemar's test: $\chi^{2}=28.3 ; P<0.001$} \\
\hline \multicolumn{7}{|l|}{ Non-supplemented } \\
\hline \multicolumn{7}{|l|}{ Last school medical examination } \\
\hline Stunted & 10 & $76 \cdot 9$ & 3 & $23 \cdot 1$ & 13 & $100 \cdot 0$ \\
\hline Normal & 4 & $02 \cdot 6$ & 150 & $97 \cdot 4$ & 154 & $100 \cdot 0$ \\
\hline \multicolumn{7}{|l|}{ McNemar's test: $\chi^{2}=0.0 ; P=1.000$} \\
\hline
\end{tabular}


Table 4. Serum vitamin A concentrations and prevalence of vitamin A deficiency by duration since supplementation*

\begin{tabular}{|c|c|c|c|c|c|}
\hline \multirow[b]{2}{*}{ Duration since supplementation } & \multicolumn{3}{|c|}{$\begin{array}{l}\text { Serum vitamin } A \text { concentrations } \\
\qquad(\mu \mathrm{mol} / \mathrm{l})\end{array}$} & \multicolumn{2}{|c|}{$\begin{array}{c}\text { Prevalence of vitamin A } \\
\text { deficiency† }\end{array}$} \\
\hline & $n$ & Mean & SD & $n$ & $\%$ \\
\hline$<1$ month & 97 & $1.6^{\mathrm{a}}$ & 0.45 & 3 & 3.1 \\
\hline $1-6$ months & 126 & $1 \cdot 4^{\mathrm{b}}$ & 0.50 & 10 & 7.9 \\
\hline $7-12$ months & 46 & $1.3^{\mathrm{C}}$ & 0.44 & 6 & $13 \cdot 0$ \\
\hline $13-18$ months & 79 & $1 \cdot 1^{\mathrm{C}}$ & 0.44 & 17 & 21.5 \\
\hline Controls & 162 & $1 \cdot 2^{\mathrm{c}}$ & 0.52 & 30 & 18.5 \\
\hline$F / \chi^{2}$ value & & $2 \cdot 747 \ddagger$ & & 20.78 & \\
\hline$P$ value & & $<0.001$ & & $<0.00$ & \\
\hline
\end{tabular}

a,b,c Mean values within a column with unlike superscript letters were significantly different $(P<0.05$; Student-Newman-Keuls test) ${ }^{*}$ For details of procedures, see p. 154.

†For vitamin A deficiency, a serum vitamin A concentration of $0.7 \mu \mathrm{mol} / \mathrm{l}$ was taken as the cut-off value. $\ddagger F$ test from ANOVA.

$\S \chi^{2}$ value.

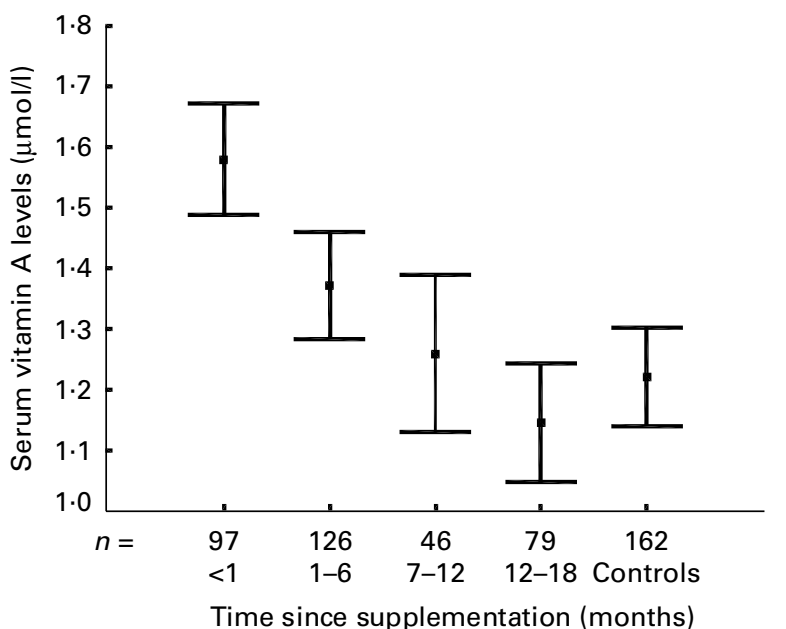

Fig. 1. Serum vitamin A levels by time since supplementation. For details of procedures, see p. 154. Values are means with their $95 \% \mathrm{Cl}$ depicted by vertical bars.

to sustain a high serum vitamin A concentration following an oral megadose depends on many factors. The higher demand for nutrients during the period of growth, inadequate consumption of vitamin A and increased catabolism of vitamin A under a heavy burden of parasitic infections are critical to the vitamin A status of a child (Semba, 1994). Some children were living on estates where a high prevalence of geo-helminth infections had been reported (Sorensen et al. 1996; Gunawardena et al. 2005). Supplemented children came from a poorer socioeconomic background and this may be a reason for their inability to sustain a high serum vitamin A level after 6 months of supplementation.

The single most important predictor of vitamin A levels was the time since supplementation, with vitamin A levels declining over time. Immediately after supplementation, vitamin A levels may increase by as much as $0.4 \mu \mathrm{mol} / 1$, i.e. a $30-40 \%$ increase in serum levels. By the end of 6 months this drops by about $0 \cdot 2 \mu \mathrm{mol} / \mathrm{l}$.

The dose of $105 \mu \mathrm{mol}$ (100000 IU) used in the supplementation programme in Sri Lanka may be a reason for the rapid decline in vitamin A levels. Different dosage and frequency forms have been used elsewhere. Most studies using a megadose of $210 \mu \mathrm{mol}$ (200000 IU) for supplementation every $3-4$ or 6 months report beneficial effects despite co-existing malnutrition and heavy infectious disease burdens (Sommer et al. 1986; West et al. 1991; Daulaire et al. 1992). In Africa, the Ghana Vast Study Team (1993) trial reported the beneficial effects of vitamin A supplementation on morbidity and mortality on children over 1 year with children receiving $210 \mu \mathrm{mol}$ every 4 months. Herera et al. (1992) reported that a 6-monthly dosing schedule of vitamin A supplementation had no impact on child survival in Sudan. Similarly, Pedro et al. (2004) reported that the effect of high-dose vitamin A capsules on serum retinol concentrations do not persist for 6 months in children from 1 to 5 years of age in the Philippines.

The success of a vitamin A supplementation programme using an oral megadose relies on the body's ability to store vitamin A. The bulk of the body's vitamin A is stored as retinyl esters in the liver. To meet constant tissue needs, despite day-to-day variability of dietary vitamin A, a steady concentration of circulating retinol is maintained by drawing on hepatic reserves through secretion of retinol bound to its specific carrier protein, retinol-binding protein (Gamble et al. 2001). Protein deficiency status reduces the absorption of vitamin $\mathrm{A}$, and the synthesis and release of retinol-binding protein from the liver. In such situations, an oral megadose supplementation programme will be ineffective.

Donnen et al. (1998) reported that high-dose supplementation of vitamin A did not reduce morbidity in malnourished and vitamin A-deficient children, and recommended a daily low-dose vitamin A supplementation for severely malnourished children. There is evidence that weekly low-dose supplementation is more effective than periodic megadose supplementation (Rahmathullah et al. 1990). More frequent supplementation schedules have inherent practical problems associated with their implementation.

Baseline vitamin A status may influence the impact of a supplementation programme. It has been reported that serum concentrations will only increase if they are already low and low concentrations are due to vitamin A deficiency (Olson, 1984). We could not elucidate baseline values as the survey was a cross-sectional survey. Considering average vitamin A concentrations of children which ranged from 1.4 (SD 0.49) 
Table 5. Regression analysis using serum vitamin A levels ( $\mu \mathrm{mol} / \mathrm{l})$ as the dependent variable

\begin{tabular}{|c|c|c|c|c|c|}
\hline Independent variable & $\beta^{*}$ & df & SE & $F / t$ value & $P$ value \\
\hline Intercept & 1.315 & 1 & & & \\
\hline Supplementation $\dagger$ & & 4 & & $7.407 \ddagger$ & $<0.001$ \\
\hline$<1$ month & 0.348 & 1 & 0.071 & $4.918 \S$ & $<0.001$ \\
\hline $1-6$ months & 0.173 & 1 & 0.065 & $2 \cdot 665 \S$ & 0.008 \\
\hline $7-12$ months & 0.082 & 1 & 0.089 & $0.951 \S$ & 0.342 \\
\hline $12-18$ months & -0.014 & 1 & 0.079 & $-0.177 \S$ & 0.859 \\
\hline Sex\| & -0.093 & 1 & 0.049 & $-1.902 \S$ & 0.058 \\
\hline Mothers' educational status & & 2 & & $1.042 \ddagger$ & 0.353 \\
\hline Up to primary & -0.102 & 1 & 0.078 & $-1 \cdot 307 \S$ & 0.192 \\
\hline Secondary & -0.006 & 1 & 0.057 & $-0.104 \S$ & 0.917 \\
\hline Father's educational status ${ }^{\star \star}$ & & 2 & & $0.280 \ddagger$ & 0.756 \\
\hline Up to primary & -0.034 & 1 & 0.073 & $-0.470 \S$ & 0.639 \\
\hline Secondary & 0.014 & 1 & 0.058 & $0.242 \S$ & 0.809 \\
\hline Type of houset† & -0.028 & 1 & 0.055 & $-0.502 \S$ & 0.616 \\
\hline 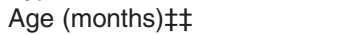 & -0.001 & 1 & 0.001 & $-0.363 \ddagger$ & 0.716 \\
\hline
\end{tabular}

${ }^{\star}$ Regression coefficient.

†Reference group is the control group.

$\ddagger F$ test.

$\S t$ test.

$\|$ Reference group is female children

I Reference group is education above Grade 9.

${ }^{\star *}$ Reference group is education above Grade 9.

†† Reference group is permanent house type.

㧊Reference group is children $\geq 5$ years.

to 1.2 (SD 0.52$) \mu \mathrm{mol} / 1$ for supplemented and control groups, respectively, there is very little evidence to suggest a high prevalence of vitamin A deficiency or extreme deficiency among these children. The average serum vitamin A concentrations in children of the present study were similar to those reported in the UK (Thurnham et al. 2005) and USA (Ballew et al. 2001), though measured using different assays. It is possible that the impact of a single mega dose supplementation of $105 \mu \mathrm{mol}$ vitamin A observed in the present study may be due to the relatively low prevalence of vitamin A deficiency in this population.

Serum vitamin A levels and the prevalence of ocular manifestations of deficiency are important outcome indicators in evaluating vitamin A intervention programmes (Wasantwisut, 2002). Though vitamin A concentrations were significantly different between non-supplemented and supplemented children 6 months before the survey, there was no significant difference in the prevalence of ocular manifestations of vitamin A deficiency or morbidity between the two groups of children. It may be concluded that a single dose of $105 \mu \mathrm{mol}$ vitamin A improved serum vitamin A concentrations significantly in the short term but the effect on morbidity was not clear.

Night blindness and conjunctival xerosis are often associated with poor nutritional status, particularly stunting (Brink et al. 1979; Santos et al. 1983). There are reports that vitamin A supplementation improves linear growth (Arroyave et al. 1979; Muhilal et al. 1988; Hadi et al. 2000). Even though the single administration of a $105 \mu \mathrm{mol}$ megadose may be inadequate to sustain high levels after 6 months, there is evidence suggestive that it may have a beneficial effect on nutritional status of children as documented by the reduction in the prevalence of stunting in supplemented children. However, the present results need to be interpreted with caution given the baseline differences, and age and sex differences between the two groups.
A typical child in a developing country would need to increase the portion size of fruits and vegetables by about 10-fold to control vitamin A deficiency by eating fruits and vegetables alone, a goal which cannot be achieved (Miller et al. 2002). Therefore, without supplementation, a child in a developing country is not able to attain and maintain 'minimally adequate' vitamin A stores in the liver. The WHO recommends a dose of $210 \mu \mathrm{mol}$ vitamin A every 4-6 months for children above 1 year of age (World Health Organization, 2000). Hence, the dose of $105 \mu \mathrm{mol}$ every 3 years used in Sri Lanka for school children is grossly inadequate.

The problem of overdosing may be the single most important reason for using the current dosing schedule. Only about $1 \%$ of children showed signs of intolerance to $210 \mu \mathrm{mol}$ retinyl palmitate in acid solution, which disappeared after a few hours (Arroyave, 1988). Sommer (1996) did not report any deaths linked to isolated vitamin A toxicity. Studies conducted among preschool children receiving $210 \mu \mathrm{mol}$ every 4-6 months reported no overdosing signs and symptoms (Sommer et al. 1986; West et al. 1991; Daulaire et al. 1992).

In Sri Lanka, vitamin A deficiency has been a long-felt public health problem and there was no sustained programme prior to the current supplementation programme. Although supplementation with high-dose vitamin A is the most widely used strategy to combat vitamin A deficiency, other strategies have been adopted or are being considered in other countries. These include food fortification, homestead food production and social marketing (Bloem et al. 2002). Revising the dosing schedule coupled with other interventions may produce better results.

\section{Acknowledgements}

We thank the staff of the MOH/DDHS Office, Yatiyantota, Kegalle for their assistance in data collection, Dr Gayathri 
Gauthamadasa and Dr S. M. Dunuwila for assisting in conducting clinical examinations, and Dr Renu Wickremasinghe and the staff of the Departments of Parasitology and Biochemistry of the Faculty of Medical Sciences, University of Sri Jayewardenepura, Sri Lanka for their assistance in analysing serum samples.

\section{References}

Arroyave G (1988) Risk and abuse of megadose of vitamins. Food Nutr Bull 10(2), 21-25.

Arroyave G, Aguilar JR, Flores M \& Gunzman MA (1979) Evaluation of Sugar Fortification with Vitamin A at the National Level. Washington, DC: Pan African Health Organization.

Ballew C, Bowman BA, Sowell AL \& Gillespie C (2001) Serum retinal distributions in residents of the United States: third National Health and Nutrition Examination Survey, 1988-1994. Am J Clin Nutr 73, 586-593.

Bieri JG, Tolliver TJ \& Catignani GL (1979) Simultaneous determination of $\alpha$-tocopherol and retinol in plasma or red cells by high pressure liquid chromatography. Am J Clin Nutr 32, 2143-2149.

Bloem MV, Kiess L \& Moench-Pfannner R (2002) Process indicator for monitoring and evaluating vitamin A programs. Proceedings of the XX International Vitamin A Consultative Group Meeting. $J$ Nutr 132, 2934S-2939S.

Brink EW, Perera WDA, Broske SP, Cash RA, Smith JL, Sauberlich HE \& Bashor MM (1979) Vitamin A status of children in Sri Lanka. Am J Clin Nutr 32, 84-92.

Daulaire NMP, Starbuck ES, Houston RM, Church MS, Stukel TA \& Pandey MR (1992) Childhood mortality after a high dose of Vitamin A in a high risk population. Br Med $J$ 304, 207-210.

Donnen P, Dramaix M, Brasseur D, Bitwe R, Vertongen F \& Hennart P (1998) Randomized placebo-controlled clinical trial of the effect of a single high dose or daily low dose Vitamin A on the morbidity of hospitalized, malnourished children. Am J Clin Nutr 68, 1254-1260.

Family Health Bureau (2000) Vitamin A Deficiency Disorders: Family Health Update. Colombo: Family Health Bureau.

Gamble VM, Rajasekhar R, Palafox NA, Briand K, Berglund L \& Blaner WS (2001) Retinol binding protein as a surrogate measure for serum retinol: studies in Vitamin A-deficient children from the Republic of the Marshall Island. Am J Clin Nutr 73, 594-601.

Ghana Vast Study Team (1993) Vitamin A supplementation in northeastern Ghana; effects on clinic attendance, hospital admissions and child mortality. Lancet 342, 7-12.

Gunawardena GS, Karunaweera ND \& Ismail MM (2005) Effects of climatic, socio-economic and behavioural factors on the transmission of hookworm (Necator americanus) on two low-country plantations in Sri Lanka. Ann Trop Med Parasitol 99, 601-609.

Hadi H, Stoltzfus RJ, Dibley M, Moulton LH, West KP Jr, Kjolhede CL \& Sadjimin T (2000) Vitamin A supplementation selectively improves the linear growth of Indonesian preschool children: result from a randomized controlled trial. Am J Clin Nutr 71, 507-513.

Herera MG, Nestel P, El Amin A, Fawzi WW, Mohamed KA \& Weld L (1992) Vitamin A supplementation and child survival. Lancet 340, 267-271.

Medical Research Institute (1998) Vitamin A Deficiency Status of Children, Sri Lanka 1995/96 (A Survey Report). Colombo: Ministry of Health.
Miller M, Humphrey J, Johnson E, Marinda E, Brookmeyer R \& Kartz J (2002) Why do children become vitamin A deficient? Proceedings of the XX International Vitamin A Consultative Group Meeting. J Nutr 132, 2867S-2880S.

Muhilal PD, Idjradinata YR, Muherdiyantiningsih \& Karyadi D (1988) Vitamin A-fortified monosodium glutamate and health, growth, and survival of children; a controlled field trial. Am J Clin Nutr 48, 1271-1276.

Nutrition Division (1999) Control of Vitamin A Deficiency in Sri Lanka - A Policy Document. Colombo: Ministry of Health.

Olson JA (1984) Serum levels of vitamin A and carotenoids

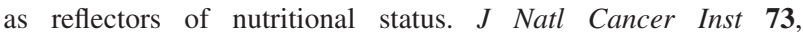
1439-1444.

Pedro MRA, Madriaga JR, Barba CVC, Habito RCE, Gana AE, Deitchler M \& Mason JB (2004) The national vitamin A supplementation programme and subclinical vitamin A deficiency among preschool children in the Philippines. Food Nutr Bull 25, $319-329$.

Rahmathullah L, Underwood BA, Thulasiraj RD, Milton RC, Ramaswamy K, Rahmathullah R \& Babu G (1990) Reduced mortality among children in southern India receiving a small weekly dose of Vitamin A. N Engl J Med 323, 929-935.

Santos LMP, Dricot JM, Asciutti LS \& Dricot-d'ans C (1983) Xerophthalmia in a state of Paraiba Brazil: clinical findings. Am $J$ Clin Nutr 38, 139-144.

Semba RD (1994) Vitamin A, immunity and infections. Clin Infect Dis 19, 489-499.

Sommer A (1989) Large dose of vitamin A to control vitamin A deficiency. Int J Vitam Nutr Res Suppl 30, 37-41.

Sommer A (1996) Uses and misuses of Vitamin A. Curr Issues Public Health 2, 161-164.

Sommer A, Tarwotjo I, Djunaedi E, West KP Jr, Loeden AA \& Tilden R (1986) Impact of Vitamin A supplementation on childhood mortality; randomized controlled community trial. Lancet i, 1169-1173.

Sorensen E, Ismail M, Amarasinghe DKC, Hettiarachchi I \& Dassenaike TsdeC (1996) The prevalence and control of soil-transmitted nematode infections among children and women in the plantations in Sri Lanka. Cey Med J 41, 37-41.

Thurnham DI, Mburu ASW, Mwaniki DL \& Wagt AD (2005) Micronutrients in childhood and the influence of subclinical inflammation. Proc Nutr Soc 64, 502-509.

Wasantwisut E (2002) Recommendation for monitoring and evaluating vitamin A programs; outcome indicators. J Nutr 132, 2940S-2942S.

West KP Jr, Pokhrel RP \& Katz J (1991) Efficacy of Vitamin A in reducing preschool child mortality in Nepal. Lancet 338, $67-71$.

World Health Organization (1995a) Vitamin A Deficiency and its Consequences. A Field Guide to Detection and Control, 3rd ed. Geneva: WHO.

World Health Organization (1995b) Physical Status: The Use and Interpretation of Anthropometry. Technical Report Series no. 746. Geneva: WHO.

World Health Organization (1996) Indicators for Assessing Vitamin A Deficiency and Their Application in Maintaining and Evaluating Intervention Programmes. Geneva: WHO.

World Health Organization (2000) Report of an Informal Consultation on Vitamin A Supplementation. Geneva: WHO. 